\title{
Organizational Behaviour: Exploring The Relationship Between Ethical Climate, Self-Efficacy And Hope
}

Sonia Swanepoel, North-West University, Mmabatho, South Africa

PA Botha, North-West University, Mmabatho, South Africa Rusty Rose-Innes, Consultant, Pretoria, South Africa

\begin{abstract}
This article explicates the extent to which ethical climate, self-efficacy and hope are related. The objective of the study was to determine if a relationship exist between ethical climate, hope and self-efficacy. The relationship between these constructs has not been researched previously. This research will add to the body of knowledge. Three questionnaires, namely Victor and Cullen's Ethical Climate Questionnaire (ECQ) (1987), the State Hope Scale (SHS) developed by Snyder, Sympson, Ybasco, Borders, Babyak and Higgins (1996), and the Self-Efficacy Scale (SES) of Sherer, Maddux, Mercandante, Prentice-Dunn, Jacobs and Rogers (1982), were combined into one questionnaire and used to measure 97 participants' responses. Various sources were compared using the Grounded Theory (GT) method. Descriptive, correlational, and inferential statistics were applied to determine the relationship between ethical climate, hope and selfefficacy. The Bravais-Pearson product-moment-correlation denotes a significant relationship between the ECQ, SHS and SES. The results demonstrate the plausibility of the integrated organizational behaviour model, which provides a new perspective on the influence of hope and self-efficacy on ethical climate.
\end{abstract}

Keywords: Organizational Behaviour; Ethical Climate; Self-Efficacy Hope

\section{INTRODUCTION}

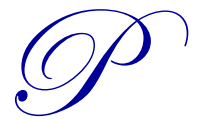

resent-day organisations are faced with many uncertainties associated with a turbulent business environment. The construct of positive psychological capital (consisting of hope, resilience and efficacy) directly influences organisational climate (Luthans, Norman, Avolio \& Avey, 2008). Studies in the positive organisational field indicate benefits to organisations. (Luthans, \& Youssef, 2007). This research explores if hope and self-efficacy relates to ethical climate as an element of organisational behaviour.

A high-hope and high-self-efficacy organisational culture may be the result of strategies, reward systems and leadership (Adnan, Jamil \& Nor, 2012; Jenkins, Wiklund \& Brundin, 2012; Joo, Lim \& Kim, 2013).

The literature indicates that studies in the field of organisational behaviour have moved rapidly in the direction of the positive organisational direction, as is the case in other fields of psychology. Luthans (2002) emphasises that organisational theory tends to be more macro-oriented than organisational behaviour: it is more concerned with organisational structures and designs.

He defines positive organisational behaviour as: "the study and application of positively oriented human resource strengths and psychological capacities...." (Luthans, 2002:59). However, organisations tend not to understand and manage the psychological strengths such as hope and self-efficacy of their employees in the best interest of the organisation and those employees, who constitute the building blocks of an ethical climate (Luthans, 2002). 


\section{LITERATURE REVIEW}

\subsection{Ethical Climate}

During the past decade the world has been shocked by a series of scandals involving top executives at international organizations in various countries engaging in unethical practices: Enron, Worldcom, the Texas Youth Commission (TYC), Rite Aid Corporate, Bernard Madoff's Ponzi scheme, AIGSatyam Computer Services, American International Group Inc (AIG), Tyco, and most recently, the phone hacking by News of the World (part of Rupert Murdoch's News Corp) - to name but a few (De Cremer, Van Dick, Tenbrunsel, Pillutla \& Murnighan, 2011; Gonzalez-Padron, Hult \& Calantone, 2008; Shin, 2012). In South Africa, the Krion, Fidentia, and Wendy Machanik Property Holdings scandals have featured prominently in newspaper headlines during recent years (Krige, 2012).

These cases highlight the dilemma and the importance to establish an ethical climate within an organization. Yet, as noted by Shafer and Simmons (2011) and Shin (2012), ethical climate has received none or very little attention in general ethics studies.

Ethics is a moral compass or rule to determine between right and wrong, what is acceptable and unacceptable, distinguish between good and evil, virtue and vice. (Brinkman, 2002; Hornsveld \& Osman, 2013; Resnik, 2010). Ethics may mean various things to various people, it is the underlying principle of what is considered right or wrong by an individual or an organisation, and more narrowly as a set of clear 'dos and don'ts' that are formalised in organisational policies which govern the behaviour of employees and teams (Srinivasan, 2011; Wang \& Hsieh, 2012). Huang, You and Tsai (2012).

Although business ethics has received a lot of attention in literature, a universal definition cannot be found. In addition current definitions are on an abstract level. Most definitions refer to good or bad, right or wrong, ethical or unethical. To complicate the problem not everyone agrees on what is morally right or wrong (De Cremer et al., 2011; Drover, Franczak, \& Beltramini, 2012; Lewis, 1985). Lewis (1985) defines business ethics as "nailing jello on a wall". He continues to summarise the common thread of definitions namely:

- "one's business ethics cannot be separated from his or her personal ethics (or all other ethics); and

- business will never be any more than the people who are in business" (Lewis, 1985:3).

Van Vuuren (2002) describe ethical organisations as ones with strong ethical value orientations that live these values and practise them in engaging with their internal and external environments.

Ethical climate comprises a set of perceptions - psychologically meaningful constructs - that employees have of the prevailing ethical procedures and policies within their organisation (Blome \& Paulraj, 2012; Jaramillo, Mulki \& Boles, 2012). In other words, it is the unspoken understanding among employees of what constitutes acceptable behaviour and what does not. In most organisations, the moral undercurrents are apparent and employees know which way they flow (Deshpande, Joseph \& Shu, 2011; Ihlen, 2009; Post, Lawrence \& Weber, 2002; Shafer, 2009; Shin, 2012; Simha \& Cullen, 2012; Sims, 1992). Organisations with a strong ethical climate are often in a more advanced stage of ethical development, with ethical principles disseminated throughout the organisation (Brand, 2008; Conrad, 2013; Driscoll \& Hoffman, 1999; Fu \& Deshpande, 2011; Gonzalez-Padron et al. 2008). Cullen, Victor and Bronson (1993) point out that an ethical climate may constitute a discontinuity in terms of maximising self-interest and joint interests or adherence to universal principles and this view is mirrored by Laratta (2009).

Ivan Seidenberg (1998:11), former chairman and CEO of communication giant Verizon Communications Inc (as well as Verizon's predecessor companies, NYNEX and Bell Atlantic), explained the need for ethical climate as follows: "Organisations can no longer rely on traditional modus operandi [...] new behaviours grounded in business ethics are urgently required to ensure continued stakeholders' trust."

Business ethics is defined as the guiding principles and standards that organisations espouse to direct their day-to-day business activities and relations with internal and external stakeholders in accordance with established 
corporate values (Shin, 2012; Victor \& Cullen, 1987, 1988). As illustrated by Seidenberg's words above, companies are embracing ethics and value initiatives because they believe, with or without hard factual evidence, that they will have a competitive advantage if they do so.

Developmental psychologist Lawrence Kohlberg first developed his 'stages of moral development' model (1969) and expanded it over the following three decades. His model provides a theoretical basis for understanding how individuals think about ethical dilemmas and comprises six stages:

- In the first and second stages, the individual is concerned with concrete consequences, for example, external reward and punishment;

- In stages three and four, what is 'right' is that which conforms to expectations of the good of larger society; and

- In stages five and six, 'right' is determined by universal values or principles.

Kohlberg's (1984) research on moral development and Schneider's (1983) work on sociocultural theories of organisation served as the basis for Victor and Cullen on which to develop their ethical climate theory $(1987 ; 1988)$. Their ethical philosophy includes three dimensions:

- $\quad$ Egotism - behaviour concerned with self-interest;

- Benevolence - decisions and actions are taken to produce the greatest good for the greatest number of people (that is, utilitarianism); and

- $\quad$ Principle - decisions are made and actions are taken in accordance with laws, rules, codes and procedures (that is, deontology).

Cullen, Victor and Stephens (1989) maintain that it is only possible to understand ethical climate if an individual has knowledge of both organizational theory and economics. They put forward three factors that determine and identify an organisation's ethical climate, namely the environment in which the organisation operates, the type of organisation, and its history.

\subsection{Hope}

The concept of hope is a major thread running through much of Western history. It has been the subject of many analyses of a broad philosophical or cultural nature, starting with the ancient Greeks (Averill, Catlin \& Chon, 1990; Brouwer, Meijer, Weeks \& Baneke, 2008; Valle, Huebner \& Suldo, 2006).

But what is 'hope'? What the ancient dramatist Euripides called a "curse upon humanity" (quoted in Menninger, 1959:281) in the fifth century BC, the philosopher Søren Kierkegaard referred to as the "passion for the possible" (quoted in Godfrey, 2009:369 in the nineteenth century AD - and modern-day commentators share this more positive view. In the 1960s and 1970s, a number of scholars provided definitions of hope. Group one defined hope as 'the perception that one's goals could be attained' (Cantril, 1964; Frank, 1975; Melges \& Bowlby, 1969; Menninger, 1959; Stotland, 1969). The second group of scholars (Brent \& Rehm, 1979; Newell \& Simons, 1972) defined hope as the belief of a person to know how to reach a goal (Pathways) as well as the motivation to use the pathways to reach the goal (Agency).

Yavas, Babakus and Karatepe (2013) describes hope as positive expectations of the future while Lynch (1965) characterises it as the deep-seated knowledge or sense that there is a way out of difficulty and that things will work out for the best; something midway between enthusiasm and knowledge. According to Farina, Hearth and Popovich (1995) (and more recently, Snyder, 2002), hope constitutes an essential experience of the human condition: a way of feeling, of thinking, of behaving and of relating to oneself and one's world. It has the ability to be fluid in its expectations, and in the event that the desired outcome does not occur, it may yet persist.

It is therefore hardly surprising that the hope construct came to play a prominent role in the domain of positive psychology in the latter years of the twentieth century. Nineteen-fifty literature highlighted the role of hope in human adaptation and scholars such as Victor Frankl (1959) suggested that a high level of belief system and a 
purpose in life provided people with the ability to endure life's hardships. Psychologists noted that a lack of hope introduces significant risk, which may lead to mental disorders, thus confirming the psychological power of hope (Magaletta \& Oliver, 1999; Valle et al., 2006; Weis \& Speridakos, 2011). During the sixties and seventies, leading American psychiatrist Jerome Frank $(1975 ; 1973 ; 1968)$ published several compelling papers and books suggesting that the generation of hope was a mediation mechanism used across differing psychotherapies - a view shared by Charles Snyder, which compelled him to further explore the power of hope in his own research and led him to conclude that it is equally important in daily living and therapy (Snyder, Feldman, Taylor, Schroeder and Adams III, 2000). In his most recent work, Snyder describes the positive psychological effect of hope as follows:

"In studying hope, so too have I observed the spectrum of human strength. This reminds me of the rainbow that frequently is used as a symbol of hope. A rainbow is a prism that sends shards of multi-coloured light in various directions. It lifts our spirits and makes us think of what is possible. Hope is the same-a personal rainbow of the mind." (Snyder, 2002:269)

According to Snyder and colleagues Rand, King, Feldman and Taylor (2002), hope, as part of positive psychology, is crucial for enhancing people's quality of life. In this regard, they identify 'primary' and 'secondary enhancements'. Primary enhancements are thoughts and actions that may be employed to establish optimal functioning and satisfaction, while secondary enhancement involves thoughts and actions that further enhance and sustain optimal functioning and satisfaction - a notion that shows some similarity to Maslow's (1970) concept of self-actualisation.

High-hope people have more positive thoughts than low-hope individuals, who tend to think negatively about themselves and the pursuit of their goals and are overwhelmed by the perceived difficulty of attaining them. They are uncertain about their future and have serious concerns about their ability to cope. Low-hope individuals generally see themselves in a favourable, biased light and engage in positive self-presentation, yet usually present themselves in an understated and self-effacing way. These characteristics tend to make it more difficult for low-hope individuals to change during the therapy process (Curry, Snyder, Cook, Ruby \& Rehm, 1997; Snyder et al., 2002; Snyder et al,. 2000).

There are general rules of hope, the first of which emphasises prudence: hope necessarily involves some uncertainty, but people should not hope for improbable outcomes. For hope to have meaning in the fullest sense, the 'possible' must take two forms: the world itself must consist of possibilities, not necessities; and human nature too must consist of possibilities. This means that, by projecting themselves into the future, people may help to create not only their own futures, but also themselves in the process. Therefore, hope is a powerful mechanism in determining not only how individuals see themselves, but also how well they perform (Averill et al. 1990; Yavas et al., 2013).

This brings us to the role of hope in organisational behaviour. In spite of research showing high correlations between hope and working alliances (Magyar-Moe, Edwards \& Lopez, 2001). Luthans (2002) contends that hope has not yet assumed an integral position in the literature on organisational behaviour. This in spite of the fact that just like optimism, emotional intelligence and self-efficacy, the hope construct seems extremely relevant to performance in the workplace.

Snyder, Irving, and Anderson (1991:287) defined hope "as a cognitive set that is based on a reciprocally derived sense of successful (a) agency (goal-directed determination) and (b) pathways (planning of ways to meet goals)." Snyder (2002) and others built on this and their own subsequent research to expand on this idea as follows:

- Goals constitute the cognitive element that drives human actions and anchors the hope theory (see also Snyder, 1998, 1994a, 1994b; Snyder, Cheavens \& Michael, 1999; Snyder, Cheavens \& Sympson, 1997). Snyder (1995) holds that human beings are goal-directed, which represents a fundamental starting point in understanding how to get to where we want to be in life.

- $\quad$ Pathways thinking tap the perceived ability to generate alternative routes to achieve set goals or outcomes. Obstacles do not impede people with strong pathway thinking; instead, they look for alternative ways to meet their desired goals (Snyder et al., 1991).

- Agency thinking - the perceived capacity to use one's pathways to reach desired goals - constitutes the 
motivational component (cognitive willpower or energy) that mobilises an individual towards achieving his or her goals and is a core element of hope theory. Thus, in Luthans' view, agency (willpower) is the motivation to develop plans (what he calls "way power") to achieve successful outcomes (2002:62), so that the hope construct acquires a power dimension that raises it above its everyday usage and other positive constructs such as optimism and self-efficacy. Snyder, LaPointe, Crowson and Early (1998: 809) reports that high-hope people embrace self-talk agency phrases such as 'I can do this' and 'I am not going to be stopped'. High-hope employees who exhibit both pathways and agency thinking (the necessary motivation) may contribute to an organisation's competitive advantage and help turn environmental threats into economic challenges (Luthans \& Jensen, 2002).

The study of hope may reflect a specific way of thinking about enhancing individual and shared future goals (Snyder et al., 2000; Yavas et al., 2013). According to these researchers, what are required are environments in which people may interact in supportive atmospheres to ensure that both individual and collective goals are achieved. Boyatzis and McKee (2006) and Walker (2006) suggest that the challenge for every manager lies in reaching inside his or her subordinates' sources of hope - therein lies the power to evoke and articulate an individual's personal, ideal self-image, as well as the shared ideals that flow from it, and to lead others in the same direction.

The hope construct and its positive role in the psychotherapy change process has been explored here. As we progress into the twenty-first century, the search for other common factors should continue to advance the collective understanding of beneficial psychotherapy processes and their relevance in organisational behaviour theory (Snyder et al., 2000).

\subsection{Self-efficacy}

Much research has been done on the role and influence of self-efficacy in the workplace, with researchers affirming its value as a managerial and human resource tool that has the psychological potential to enhance development and effective performance management (see, for example, Brown \& Inouyne, 1978; Schunk, 1981; Staples, Hulland \& Higgins, 1998; Weinberg, Gould \& Jackson, 1979).

Canadian psychologist Albert Bandura began developing the concept of self-efficacy as a mechanism in human agency in the late 1960s and has since become the world's leading self-efficacy theorist. In Bandura's view, human achievement and wellbeing require an optimistic sense of personal efficacy. Furthermore, a vigorous sense of personal efficacy is needed to sustain the persistent effort required to be successful; in fact, setbacks and difficulties in human pursuits serve a useful purpose in teaching that success usually requires sustained effort. And, having successfully coped under difficult circumstances, individuals emerge from adversity with a stronger sense of selfefficacy (Bandura, 1991; Bandura \& Schunk, 1981; Luthans, 2002); hence self-efficacy may also serve as an important and self-reinforcing motivational construct (Wood \& Bandura, 1989).

Bandura (1982) describes self-efficacy as "Efficacy in dealing with one's environment is not a fixed act or simply a matter of knowing what to do. Rather, it involves a generative capability in which component cognitive, social, and behavioural skills must be organized into integrated courses of action to serve innumerable purposes." "how well one can execute courses of action required in dealing with prospective situations" and (in collaboration with Robert Wood) "people's belief in their capabilities to mobilize the motivation, cognitive resources, and courses of action needed to exercise control over events in their lives." (Wood \& Bandura, 1989:364).

According to Bandura (2000), self-efficacy involves two components that influence the way individuals perform at a specific task, namely efficacy expectancies and outcome expectancies. Efficacy expectancies are related to an individual's confidence that s/he has the ability to successfully perform a specific task, while outcome expectancies relate to the belief that a specific behaviour will produce a given outcome. Efficacy expectancies are stronger predictors of behaviour than outcome expectancies, because people's judgements of their own capabilities influence their choices, goals, effort, thought patterns, emotional reactions and physical actions during both anticipatory and actual transactions with the environment. In terms of outcome expectancies, Bandura's self-efficacy theory distinguishes between two judgemental sources of futility: firstly, individuals may give up trying because 
they seriously doubt that they are able to do what is required; and secondly, they may be assured of their own capabilities, but give up trying because they expect their efforts to produce no results due to the unresponsiveness, negative bias or punitiveness of the external environment (Bandura, 1982).

Bandura stresses that knowledge, transformational operations and component skills are necessary, but insufficient, for accomplished performances: a capability is only as good as its execution. In this regard, he distinguishes between operative competence and functional competence, with the former requiring continuous improvement, and the latter orchestration and continuous improvisation, of multiple situational and personal subskills to manage ever-changing circumstances (Bandura, 1982).

Bandura's self-efficacy theory inspired a generation of cognitive theorists who have drawn from and expanded on his work. Their definitions of self-efficacy closely mirror Bandura's, with slight shifts in emphasis: for example, Zullig, Teoli and Valois (2011) describe self-efficacy as an individual's own judgement regarding his or her skills in terms of carrying out required behaviour or performing particular types of actions; while Nam, Yang, Lee, Lee and Seol (2011) define it as an individual's conviction that $\mathrm{s} /$ he is able to perform the actions necessary to produce a desired outcome in the face of adversity; and Joo et al., (2013) explain it as a belief in the probability that one may successfully execute some future action or task to achieve results. Gist and Mitchell (1992), as well as Kickul, Gundry, Barbosa and Whitcanack (2009), agree with Bandura that self-efficacy is one of several individual cognitive processes frequently considered in self-regulation (a comprehensive process of individual cognitive determination behaviour), while Stajkovic and Luthans (1998) base their arguments on Bandura and Wood's (1989) conceptual guidelines for the application of social cognitive theory to organisational settings.

Evidence provided by several streams of organisational research shows that self-efficacy is not limited to goal setting (Locke \& Latham, 2009), control theory (Hechavarria, Renko \& Matthews, 2011), or an integrative model of motivation and cognitive abilities (Mencl, Tay, Schwoerer \& Drasgow, 2012). McGee, Peterson, Mueller and Sequeira (2009) conducted a study comparing the five ways of operationalizing self-efficacy found in the literature, and assessed the antecedents and consequences of self-efficacy; their results confirmed that it is possible to measure self-efficacy. Moreover, self-efficacy may be learned: the assumption that individuals may be trained to have higher self-efficacy appears to be well-grounded in the literature (see, for example, Bandura, 2012; Church, Teresa, Rosebrook \& Szendre, 1992).

Along with their skills, individuals bring specific personality traits related to self-efficacy to the work situation. While self-efficacy is not considered a skill or trait per se, but rather as the reflection of an individual's confidence about whether $\mathrm{s} / \mathrm{he}$ is able to coordinate his or her abilities and skills to attain desired goals under particular circumstances and in specific domains (that is, if one performs a specific action or exhibit a certain behaviour, one may be confident that a specific, desired result will be obtained), the research has shown that employees with a high level of self-efficacy outperform those with a poor sense of self-efficacy. For example, organisations benefit handsomely when they select prospective employees on conscientiousness, as this trait affects performance through its salutary effect on self-efficacy. Conscientious employees develop greater job knowledge and produce more and higher quality output. They also develop more positive beliefs about their ability to accomplish particular tasks, so that they are more likely to set goals, which in turn results in better performance. Conversely, individuals who do not see themselves as worthy and able are less confident and tend to interpret their environment through a negative lens; hence they are more likely to view themselves as victims, and tend to be less satisfied with their jobs, themselves and their lives in general (Bandura, 1994; Bandura, 1997; Barrick, Mount and Judge, 2001; Hechavarria et al., 2011; Patrick, Care \& Ainley, 2011; Sitzmann \& Ely, 2011; Stajkovic \& Luthans, 1998; Tierney \& Farmer, 2011; Tumasjan \& Braun , 2012).

As mentioned before, research suggests that self-efficacy may be related to the internal locus of control. Individuals with high self-efficacy believe that they have control over their lives and that they can have a meaningful impact on the outcome of their lives and related events through the mobilisation of the necessary motivation, cognitive resources, and courses of action needed to exercise control over environmental events (Bandura \& Jourdan, 1991; Iskender \& Akin, 2010; Rotter,1966). Therefore, they do not permanently retreat from setbacks, but instead continue to endeavour with even greater effort (Bandura, 1997; Hechavarria et al., 2011). They focus their attention on analysing and solving problems, whereas people beset with self-doubt dwell on 
impediments, which they view as obstacles over which they can exert only limited control, and readily convince themselves that they will fail to achieve their objectives (Bandura, 2000; 2012).

It is clear from the above that the self-efficacy mechanism plays a central role in an individual employee's organisational effectiveness, as well as the collective efficacy of the organisation as a group of individual employees. In this regard, Bandura (1984) argues that shared objectives are required, and that such unifying goals must be explicit and attainable through concerted effort. He stresses the importance of the social cognitive theory, not only for its operative power to enhance the quality of human functioning in organisations, but also for its potential to nurture self-efficacy for personal and organisational gain (Bandura 1992).

In Bandura's (1982) opinion, personal inefficacy arises from the cost and demand of efficacious behaviour, which undermines the effective use of the knowledge and skills which one possesses. Yet, he also believes that selfefficacy is not a decontextualized attribute (Bandura, 1997), and argues, based on decades of research and a comprehensive theoretical understanding of the construct, that it may be enhanced or developed by means of performance accomplishments, vicarious experience, verbal persuasion, and emotional arousal.

Shantz and Latham (2012) and Van Yperen (1998) believe that developing self-efficacy in trainees may be a solution to the long-standing problem of transferring training to the job and identify specific training implications for each source of self-efficacy. Bandura (2000) categorises three specific training modalities for enhancing efficacy: guided mastery, cognitive mastery, and self-regulatory competencies. Guided mastery help employees to become successful at their tasks, while cognitive mastery modelling enhances efficacy in respect of more complex decision-making and problem-solving (Ellis, Ganzach, Castle \& Sekely, 2010). In Luthans' (2002) opinion, mastery experiences are potentially the most powerful in terms of forming efficacy beliefs, because they provide direct information about success. Bandura's own theory and research-based techniques may be used for the development of self-regulatory competencies such as self-motivation.

Leaders who practise a positive efficacy state will not only have a positive impact on their employees' performance, but will also improve their own effectiveness in the work environment

\section{THE RELATIONSHIP BETWEEN ETHICAL CLIMATE, SELF-EFFICACY AND HOPE}

Kok, Den Boer, De Vries, Gerards, Hospers and Mudde (1992) note that self-efficacy is an important determinant of behaviour and behavioural change, and that self-efficacy expectations predict the future success or failure of behaviour change programmes. This is supported by Barrick's et al., (2001) assessment that organisations benefit in numerous ways when they select applicants on conscientiousness, as this trait affects performance through its effect on positive self-efficacy. Conscientious employees develop greater job-related knowledge and produce more and higher quality output. In addition, they also develop more positive beliefs about their capabilities to accomplish particular tasks and they are more likely to set goals, which in turn result in higher performance.

Previous research focused on the relationship between self-efficacy and ethical climate (Nelson, Poms, \& Wolf, 2012; Shacklock, Manning, \& Hort, 2011; Walumbwa, Mayer, Wang, Wang, Workman, \& Christensen, 2011); hope and ethical climate (Vorster, 2011) and hope and self-efficacy (Duggleby, Cooper \& Penz, 2009; O'Sullivan, 2011; DeWitz, Woolsey, \& Walsh, 2009). No research could be found linking ethical climate, hope and self-efficacy.

\subsection{Hypotheses}

The research indicates that there are correlations between ethical climate, hope and self-efficacy:

- $\quad$ There is a positive relationship between ethical climate (Y), hope (X1) and self-efficacy (X2), which enhances ethical organisational behaviour.

- $\quad$ There is a positive relationship between ethical climate (Y) and hope (X1).

- $\quad$ There is a positive relationship between hope (X1) and self-efficacy (X2). 


\section{RESEARCH METHOD}

\subsection{Population and Sampling}

The research was conducted in the aviation industry, with a sample frame comprising 97 individuals (33 managers, 32 supervisors, and 32 employees). The gender distribution was $24,74 \%$ male and $75.26 \%$ females and the age range 29 to 59 years. The study used simple random sampling to arrive at the group of employees chosen to participate.

\subsection{Measuring Instruments}

\subsubsection{The Ethical Climate Questionnaire (ECQ)}

Victor and Cullen's $(1987,1988)$ Ethical Climate Questionnaire (ECQ) was used to assess the ethical climate within the organisation with a coefficient alpha of .72. The ECQ is based on Kohlberg's moral development research (Kohlberg 1981), the underlying assumption being that the ethical climate in organisations may be broken down into categories that are analogous to Kohlberg's ethical standards (egotism, benevolence, principle) and loci of ethical concern (individual, local, cosmopolitan). The questionnaire was designed to measure respondents' perceptions of how the members of an organisation typically make decisions regarding projects and processes (Victor \& Cullen, 1987). Based on Kohlberg's argument that the form or structure of the decision-making process is independent of the content or the range of possible outcome values of a given decision, and in order to ascertain the form of ethical reasoning, the questionnaire was designed specifically to identify organisational decision-making norms that bear direct links to supporting forms of ethical reasoning. This operationalization was in turn based on Williams' argument that "what one thinks about the subject matter of ethical thought, what one supposes it to be about, must affect what tests for acceptability or coherence [...] are appropriate to it" (1985: 73).

\subsubsection{The State Hope Scale (SHS)}

In order to tap into dispositional hope (or to assess 'the Will and the Ways') in adults, Snyder and his colleagues designed the Adult Dispositional Hope Scale (ADHS). However, the fact that the ADHS only measures trait hope (that is, an individual's general or characteristic level of hope), proved a serious drawback, as those hope levels may vary in response to specific circumstances. In response, Snyder et al. (1996) developed the State Hope Scale (SHS), a six-item, self-report questionnaire designed to measure state hope in adults and which assesses goaldirected thinking at any given moment and in any given situation (Lopez, Floyd, Ulven, \& Snyder, 2000). The SHS was applied in the research to measure how the respondents set and pursue goals and objectives and reported an overall reliability of 88 .

\subsubsection{The Self-Efficacy Scale (SES)}

Scherer et al., (1982) based their Self-Efficacy Scale (SES) on Bandura's research, which differentiated between self-efficacy expectancies. The original version of the SES consisted of 36 items, which was subsequently reduced to 23 items across two subscales, namely the General Self-Efficacy Subscale (GSESS) (17 items) and Social Self-Efficacy Subscale (SSESS) (6 items) with a reported reliability of .86. These items were rated on a 14-point Likert scale, with the GSESS (factor 1) accounting for 26.5 per cent of the total variance. The various items focused on three areas, namely the willingness to initiate behaviour; the willingness to expend effort in completing the behaviour; and persistence in the face of adversity.

\section{DATA ANALYSIS AND RESULTS}

Bravais-Pearson product-moment correlation coefficients were calculated in order to investigate the relationship between the ECQ, SHS and SES - firstly between the three scales, and then between statements related to all three scales. The results are presented in Table 1, which shows a significant positive correlation between the three scales $(\mathrm{p}<0.05)$. 
Table 1. Bravais-Pearson product moment correlation -

Ethical Climate Questionnaire (ECQ), State Hope Scale (SHS), Self-efficacy scale (SES)

\begin{tabular}{|c|c|c|c|c|}
\hline & & ECQ & SHS & SES \\
\hline \multirow[t]{3}{*}{ ECQ } & Pearson correlation & 1 & $.245^{*}$ & $.283^{*}$ \\
\hline & Sig. (2-tailed) & & .016 & .005 \\
\hline & $\mathrm{N}$ & 97 & 97 & 97 \\
\hline \multirow[t]{3}{*}{ SHS } & Pearson correlation & $.245^{*}$ & 1 & $.522 * *$ \\
\hline & Sig. (2-tailed) & .016 & & .000 \\
\hline & $\mathrm{N}$ & 97 & 97 & 97 \\
\hline \multirow[t]{3}{*}{ SES } & Pearson correlation & $.283 * *$ & $.522 * *$ & 1 \\
\hline & Sig. (2-tailed) & .005 & .000 & - \\
\hline & $\mathrm{N}$ & 97 & 97 & 97 \\
\hline
\end{tabular}

A multiple regression was performed, with the ECQ, SHS and SES as the dependent variables and the three independent variables (age, gender and level of operation) as predictors. The results of the multiple regression with ethical climate as the dependent variable are presented in Table 2, which shows that all three independent variables feature in the regression model. The standard regression coefficient, Beta, is contingent upon the dependent variables in the equation, but does not in any sense reflect the significance of the independent variables.

Table 2. Multiple regression - Ethical Climate Questionnaire (ECQ)

\begin{tabular}{|c|c|c|c|c|c|}
\hline \multirow[t]{2}{*}{ Model } & \multicolumn{2}{|c|}{ Unstandardised coefficients } & \multirow{2}{*}{$\begin{array}{c}\begin{array}{c}\text { St Standardised } \\
\text { co-coefficients }\end{array} \\
\text { B }\end{array}$} & \multirow[t]{2}{*}{$\mathbf{t}$} & \multirow[t]{2}{*}{ Sig. } \\
\hline & $\mathbf{B}$ & Std. error & & & \\
\hline 1 (Constant) & 10.302 & 0.908 & 0.013 & 11.248 & .000 \\
\hline V1 & 0.025 & 0.218 & -0.078 & 0.114 & 0.909 \\
\hline $\mathrm{V} 2$ & -0.295 & 0.409 & 0.044 & -0.722 & 0.472 \\
\hline V3 & 0.086 & 0.209 & & 0.409 & 0.684 \\
\hline
\end{tabular}

Table 2 also shows the t-statistics, with their two-tailed significance levels. The high significance levels suggest that the dependent variable and the independent variables are not linearly related. A summary table for the statistics in the equation is presented in Table 3.

Table 3. Multiple regression: ummary statistics - Ethical Climate Questionnaire (ECQ)

\begin{tabular}{ccccc}
\hline Model & $\mathbf{R}$ & R square & Adjusted R square & Std. error of the estimate \\
\hline 1 & $.091^{a}$ & .008 & -.024 & 1.77968 \\
\hline
\end{tabular}

As is evident from Table 3, the Multiple $\mathrm{R}$ is 0,091 , which results in an $\mathrm{R}^{2}$ of 0,00828 , indicating that the independent variables do not fall on the regression line.

Table 4. Multiple regression - State Hope Scale (SHS)

\begin{tabular}{|c|c|c|c|c|c|}
\hline \multirow[t]{2}{*}{ Model } & \multicolumn{2}{|c|}{ Unstandardised coefficients } & \multirow{2}{*}{$\begin{array}{c}\begin{array}{c}\text { Standardised } \\
\text { coefficients }\end{array} \\
\text { B } \\
\end{array}$} & \multirow[t]{2}{*}{$\mathbf{t}$} & \multirow{2}{*}{ Sig } \\
\hline & B & Std. error & & & \\
\hline 1 (Constant) & 26.830 & 1.955 & & 13.722 & .000 \\
\hline V1 & -0.31 & .469 & -.007 & -.065 & .948 \\
\hline $\mathrm{V} 2$ & .927 & .880 & .112 & 1.054 & .295 \\
\hline V3 & .622 & .451 & .147 & 1.379 & .171 \\
\hline
\end{tabular}

Table 4 presents the SHS as the dependent variable. It is evident from this table that all three predictors appear in the model. However, the t-scores are insignificant, which suggests that no linear relationship exists between the dependent and independent variables.

Table 5. Summary statistics - State Hope Scale (SHS)

\begin{tabular}{ccccc}
\hline Model & R & R square & Adjusted R square & Std. error of the estimate \\
\hline 1 & $.173^{a}$ & .030 & -.001 & 3.83284 \\
\hline
\end{tabular}


The results of the summary statistics are presented in Table 5. It shows that there is virtually no linear relationship between the dependent and independent variables.

Table 6. Multiple regression - Self-efficacy Scale (SES)

\begin{tabular}{|c|c|c|c|c|c|}
\hline \multirow[t]{2}{*}{ Model } & \multicolumn{2}{|c|}{ Unstandardised coefficients } & $\begin{array}{c}\text { Standardised } \\
\text { coefficients }\end{array}$ & \multirow[t]{2}{*}{$\mathbf{t}$} & \multirow[t]{2}{*}{ Sig. } \\
\hline & $\mathbf{B}$ & Std. error & $\mathbf{B}$ & & \\
\hline 1 (Constant) & 88.478 & 4.054 & & 21.823 & .000 \\
\hline V1 & .621 & .972 & .071 & 639 & .524 \\
\hline V2 & -.036 & 1.824 & -.002 & -.020 & .984 \\
\hline V3 & .806 & .934 & .093 & .862 & .391 \\
\hline
\end{tabular}

The multiple regression model with the SES as the dependent variable is presented in Table 6. Again, as is the case with the other two dependent variables, the t-score values are insignificant, indicating the absence of a linear relationship between dependent and independent variables.

Table 7. Summary statistics - Self-efficacy Scale (SES)

\begin{tabular}{ccccc}
\hline Model & R & R square & Adjusted R square & Std. error of the estimate \\
\hline 1 & $.100^{a}$ & .010 & -.022 & 7.94763 \\
\hline
\end{tabular}

The summary statistics for the SES are presented in Table 7. It is evident that there is virtually no linear relationship between the dependent and independent variables $\left(\mathrm{R}=1.00 ; \mathrm{R}^{2}=0.010\right)$.

Descriptive statistics showed that the distribution of all three dependent variables across the independent variables is, to a greater or lesser extent, skewed and that the distribution peak is not mesokurtic. The standard error of the mean suggested that it is not possible to draw inferences about the population mean with any confidence. The standard deviations are large; in consequence, deviations from the mean scores are small. As noted previously, the Bravais-Pearson product-moment correlation between the three dependent variables was also calculated, revealing significant correlation between the ECQ, SHS and SES.

The individual statements of the measuring instrument were also compared, with the results showing positive, negative and insignificant relationships. A two-way analysis of variance showed that the two-way interactions of the three main independent variables have no significant influence on the three main dependent variables. The three-way interaction between level of operation, gender and age has a significant influence only in the case of the SHS. The results of the discriminant analysis indicated that the discriminant functions are poor, with not a single independent variable appearing in the analysis.

Inferential statistics were calculated by means of Student's t-test and one-way analysis of variance, as well as the Mann-Whitney U-test (a non-parametric test for two independent samples) with regard to the dependent variable gender, because of the large discrepancy between the female and male categories (with females predominating $(\mathrm{N}=79)$ ). Neither the t-test nor the Mann-Whitney U-test revealed any significant differences. No significant differences were detected either between the three independent variables and their subgroups by means of one-way analysis of variance and post hoc tests.

Given the small subgroups of the three main independent variables, a non-parametric analysis of variance, the Kruskal-Wallis one-way analysis of variance, was performed. This test also revealed no significant differences. As regards multiple regression, it was found that all three main independent variables appear in the regression model.

\section{DISCUSSION}

This study examined the relationship between self-efficacy, hope and ethical climate. An individual's cognitive development stage determines how $\mathrm{s} / \mathrm{he}$ thinks about ethical issues and decides what is right or wrong in a given situation. Individual and situational variables interact with the cognitive component to determine how an individual is likely to behave with regard to ethical issues. It is proposed that self-efficacy influences the way in which individuals act on cognitions of what is right or wrong and whether they believe in their own abilities. 
In the workplace, employees are challenged to achieve organisational and personal goals and to find alternative ways of doing so when confronted with hurdles. Gore (2006) asserts that individuals with high levels of self-efficacy show greater cognitive resourcefulness, strategic flexibility, and effectiveness in managing their environment. A strong sense of self-efficacy also inspires people to set challenging personal goals and to achieve them, while their value systems determine their moral behaviour when confronted with ethical issues in the work environment. The relationship between ethical climate and self-efficacy as measured by the Bravais-Pearson product-moment correlation coefficient shows a positive relationship between the two variables.

However, there are also other variables that may influence ethical climate. Luthans (2002) discusses a number of variables that may impact on leadership and ethical climate in present-day organisations in their positive approach to leadership. He stresses the importance of realistic optimism, emotional intelligence, locus of control, happiness, perseverance, achievement, trust and fairness, but suggests that, with the possible exception of efficacy, hope may prove to be one of the most robust components of a positive approach to leadership.

\section{AN INTEGRATED ORGANISATIONAL BEHAVIOUR MODEL}

The research combined three established research instruments, the Ethical Climate Questionnaire, the State Hope Scale and the Self-Efficacy Scale to explore the relationship between self-efficacy, hope and ethical climate in the workplace. The results were subjected to statistical data analysis to arrive at an integrated organisational behaviour model (Figure 1), which shows how hope and self-efficacy may influence the ethical climate within organisations.

Figure 1. An integrated organizational behavior model

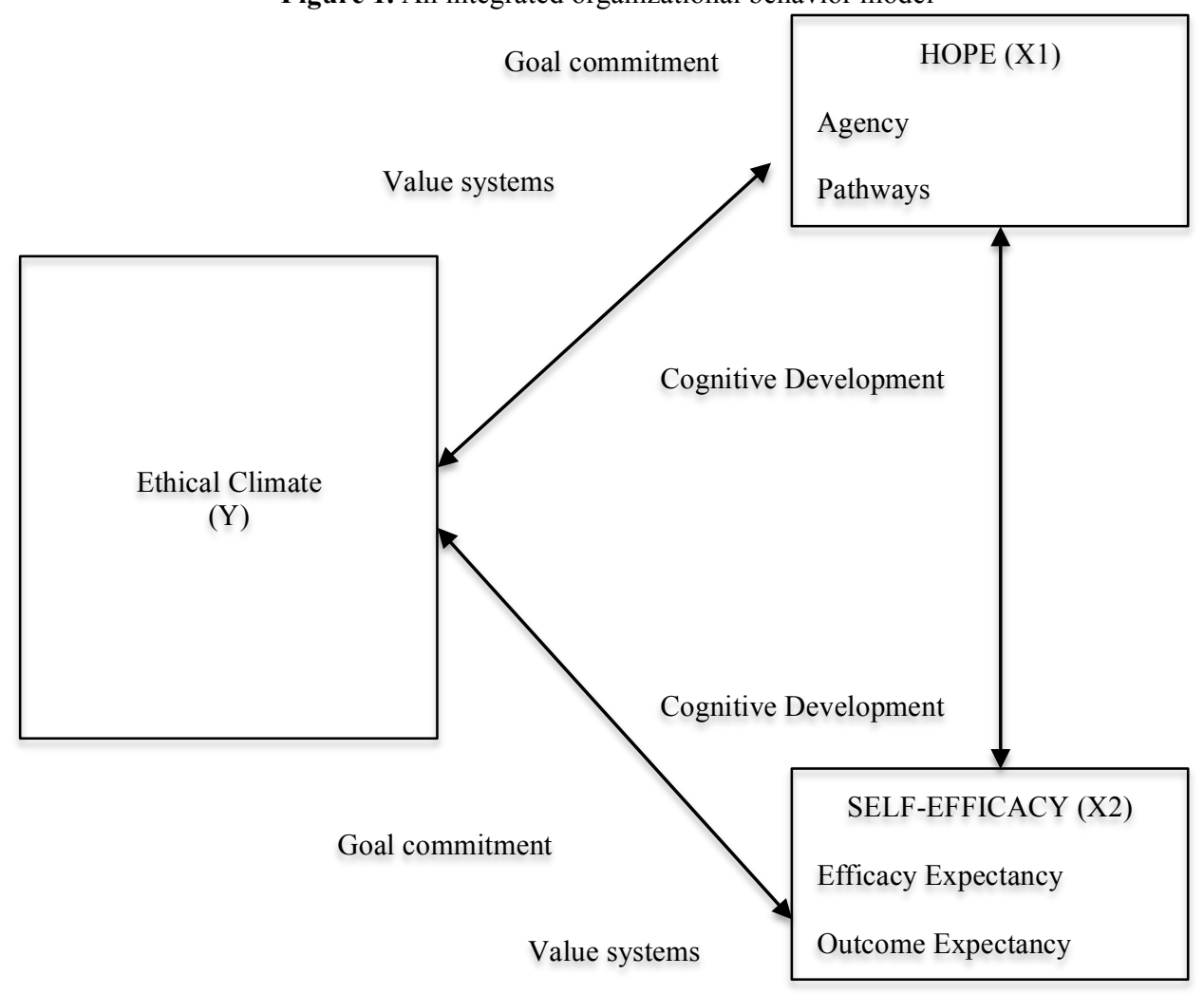

\section{CONCLUSION}

Hope and self-efficacy influence how an individual acts on cognitions of right and wrong. High-hope and high-self-efficacious individuals believe in themselves and are able to rise to the challenge to achieve organisational and personal goals, while their personal moral value systems determine how they will behave when faced with 
ethical issues in the work environment. However, the characteristics of a given job and the moral content of the organisational culture may also have an impact on the moral development of the individual.

The conceptual richness of social cognitive theory and the implications that self-efficacy may have on human performance in organisations can no longer be ignored by managers and supervisors as being too theoretical or difficult to apply. The theory offers several major advantages for the field of psychology as it relates to organisational behaviour, and organisations would do well to utilise what it reveals with regard to the potential of human resources and the role they can play in meeting competitive demands (Stajkovic \& Luthans 1998).

\section{AUTHOR INFORMATION}

Professor Sonia Swanepoel is the Executive Dean of the Faculty of Commerce and Administration at North West University in South Africa. Her current research interests are organisational behaviour, leadership, psychological capital, trust, ethical climate, personality assessment, stress and talent management. E-mail: sonia.swanepoel@nwu.ac.za (Corresponding author)

Professor Petrus Botha is the Executive Dean of the Faculty of Human and Social Sciences at North West University in South Africa. His current research interests focus on public management, organisational behaviour and management, wellness, and strategic management and thinking. E-mail: petrus.botha@nwu.ac.za

Dr. Rusty Rose-Innes current research interests are organisational behaviour, management, leadership, adult education and strategic management. E-mail: mymail.rustyri@gmail.com

\section{REFERENCES}

Adnan, N.L.B., Jamil, C.Z.M., \& Nor, N.A.M. (2012). Ethical antecedents of dysfunctional behaviour in performance measurement and control system. Asian Social Science, 9(1):29-?. DOI: 10.5539/ass.v9n1p29.

Averill, J.R., Catlin, G., \& Chon, K.K. (1990). Rules of hope. New York: Springer-Verlag.

Bandura, A. (1982). Self-efficacy mechanism in human agency. American Psychologist, 37:122-147. DOI: 10.1037/0003066X.37.2.122.

Bandura, A. (1984). Recycling misconceptions of perceived self-efficacy. Cognitive Therapy and Research, 8:231-255.

Bandura, A. (1991). Social cognitive theory of self-regulation. Organizational behavior and human decision processes, 50(2): 248-287.

Bandura, A. (1992). Exercise of personal agency through the self-efficacy mechanism. In: R Schwarzer (ed). Self-efficacy: Thought control of action. pp 355-394. Washington, DC: Hemisphere.

Bandura, A. (1994). Self-efficacy. In: VS Ramachaudran (ed). Encyclopedia of Human Behaviour, 4:71-81. New York: Academic Press.

Bandura, A. (1997). Self-efficacy: The exercise of control. New York: Freeman.

Bandura, A. (2000). The Black Handbook of Principles of organisational Behaviour. Oxford, UK: Blackwell.

Bandura, A. (2012). On the functional properties of perceived self-efficacy revisited. Journal of Management, 38(1):9-41. DOI: $10.1177 / 0149206311410606$.

Bandura, A., \& Jourdan, F.J. (1991). Self-regulatory mechanisms governing the impact of social comparison on complex decision making. Journal of Personality and Social Psychology, 60:941-951.

Bandura, A., \& Schunk, D.H. (1981). Cultivating competence, self-efficacy, and intrinsic interest through proximal selfmotivation. Journal of Personality and Social Psychology, 41(3):586-598. DOI: 10.1037/0022-3514.41.3.586.

Bandura, A. \& Wood, R.E. (1989). Effect of perceived controllability and performance standards on self-regulation of complex decision-making. Journal of Personality and Social Psychology, 56:805-814. DOI: 10.1037/0022-3514.56.5.805.

Barrick, M.R., Mount, M.K., \& Judge, T.A. (2001). Personality and performance at the beginning of the new millennium: What do we know and where do we go next? International Journal of Selection and Assessment, 9:9-30. DOI: 10.1111/14682389.00160 .

Blome, C., \& Paulraj, A. (2012). Ethical climate and purchasing social responsibility: A benevolence focus. Journal of Business Ethics (September 2012). DOI: 10.1007/s10551-012-1481-5.

Boyatzis, R., \& McKee, A. (2006). Intentional change. Journal of organisational Excellence, 25(3):49-60. DOI: $10.1002 /$ joe.20100.

Brand, H.E. (2008). Proposing and evaluating a model for ethical recruitment and selection. Journal of Contemporary Management, 5:205-222.

Brent, C.R., \& Rehm, J. (1979). Role of Hope in Academic and Sport Achievement. Journal of Personality and Social 
Psychology, 73(6): 1257-1267.

Brinkmann, J. (2002). Business and marketing ethics as professional ethics. Concepts, approaches and typologies. Journal of Business Ethics, 41(1-2), 159-177. DOI: 10.1023/A:1021318710382

Brouwer, D., Meijer, R.R., Weeks, A.M., \& Baneke, J.J. (2008). On the dimensionality of the dispositional hope scale. Psychological Assessment, 20(3):310-315. DOI: 10.1037/1040-3590.20.3.310.

Brown, I., \& Inouyne, D.K. (1978). Learned helplessness through modelling: The role of perceived similarity in competence. Journal of Personality and Social Psychology, 36(8):900-908.

Cantril, H. (1964). The human design. Journal of Individual Psychology, 20 (2): 129-136.

Church, A.T., Teresa, J.S., Rosebrook, R., \& Szendre, D. (1992). Self-efficacy for careers and occupational consideration in minority high school equivalency students. Journal of Counselling Psychology, 39:498-508.

Conrad, A.M. (2013). Ethical leadership in Kazakhstan: An exploratory study. The Journal of Values-Based Leadership, 6(1): Article 2.

Cullen, J.B., Victor, B., \& Bronson, J.W. (1993). The ethical climate questionnaire: An assessment of its development and validity. Psychological Reports, 73(2):667-674. DOI: 10.2466/pr0.1993.73.2.667.

Cullen, J.B., Victor, B., \& Stephens, C. (1989). An ethical weather report: Assessing the organisation's ethical climate. Organisational Dynamics, 18(2):50-62. DOI: 10.1016/0090-2616(89)90042-9.

Curry, L.A., Snyder, C.R., Cook, D.L., Ruby, B.C., \& Rehm, M. (1997). The role of hope in student-athlete academic and sport achievement. Journal of Personality and Social Psychology, 73:1257-1267.

De Cremer, D., Van Dick, R., Tenbrunsel, A., Pillutla, M., \& Murnighan, J. K. (2011). Understanding ethical behavior and decision making in management: A behavioural business ethics approach. British Journal of Management, 22(s1), S1S4. DOI: 10.1111/j.1467-8551.2010.00733.x

Deshpande, S.P., Joseph, J., \& Shu, X. (2011). Ethical climate and managerial success in China. Journal of Business Ethics, 99:527-534. DOI:10.1007/s10551-010-0666-z.

DeWitz, S. J., Woolsey, M. L., \& Walsh, W. B. (2009). College student retention: An exploration of the relationship between self-efficacy beliefs and purpose in life among college students. Journal of College Student Development, 50 (1), 1934. DOI: $10.1353 /$ csd.0.0049

Driscoll, D., \& Hoffman, W.M. (1999). Gaining the ethical edge: procedures for delivering values-driven management. Long Range Planning, 32(2):179-189.

Drover, W., Franczak, J., \& Beltramini, R. F. (2012). A 30-Year Historical Examination of Ethical Concerns Regarding Business Ethics: Who's Concerned?. Journal of business ethics, 111(4), 431-438. DOI: 10.1007/s10551-012-1214-9

Duggleby, W., Cooper, D., \& Penz, K. (2009). Hope, self-efficacy, spiritual well-being and job satisfaction. Journal of advanced nursing, 65(11), 2376-2385. DOI: 10.1111/j.1365-2648.2009.05094.x

Ellis, S., Ganzach, Y., Castle, E., \& Sekely, G. (2010). The effect of filmed versus personal after-event reviews on task performance: the mediating and moderating role of self-efficacy. Journal of Applied Psychology, 95(91):122-131. DOI: $10.1037 / \mathrm{a} 0017867$.

Farina, C.J., Hearth, A.K., \& Popovich, J.M. (1995). Hope and hopelessness: Critical clinical constructs. Thousand Oaks, CA: Sage.

Frank, J.D. (1975). The faith that heals. The Johns Hopkins Medical Journal, 137:127-131.

Frank, J.D. (1973). Persuasion and healing: a comparative study of psychotherapy. $2^{\text {nd }}$ Ed. Baltimore, MD: Johns Hopkins University Press.

Frank, J.D. (1968). The role of hope in psychotherapy. International Journal of Psychiatry, 5:383-395.

Frankl, V. (1959). Man's search for meaning: An introduction to logotherapy. Boston: Beacon.

Fu, W., \& Deshpande, S.P. (2011). Antecedents of organisational commitment in a Chinese construction company. Journal of Business Ethics, 109(3):301-307. DOI: 10.1007/s10551-011-1128-y.

Gist, M.E., \& Mitchell, T.R. (1992). Self-efficacy: A theoretical analysis of its determinants and malleability. Academy of Management Review, 17(2):183-211.

Godfrey, J.J. (2009). The Sufficiency of Hope. International Philosophical Quarterly, 20(3):368-370. DOI: 10.5840/ipq198020334.

Gonzalez-Padron, T., Hult, G.T.M., \& Calantone, R. (2008). Exploiting innovative opportunities in global purchasing: An assessment of ethical climate and relationship performance. Industrial Marketing Management, 37:69-82. DOI: 10.1016/j.indmarman.2007.06.013.

Gore, Jr P.A. (2006). Academic self-efficacy as a predictor of college outcomes: two incremental validity studies. Journal of Career Assessment, 14(1):92-115. DOI: 10.1177/1069072705281367.

Hornsveld, A., \& Osman, L. (2013). Ethics-why me?: professional practice. SA Pharmacist's Assistant, 13(4), 2-4.

Hechavarria, D.M., Renko, M., \& Matthews, C.H. (2011). The nascent entrepreneurship hub: goals, entrepreneurial self-efficacy and start-up outcomes. Small Business Economics, 39:685-701. DOI 10.1007/s11187-011-9355-2.

Huang, C., You, C., \& Tsai, M. (2012). A multidimensional analysis of ethical climate, job satisfaction, organisational commitment, and organisational citizenship behaviors. Nursing Ethics, 19(4):513-529. DOI: $10.1177 / 0969733011433923$.

Ihlen, O. (2009). The climate response of the world's 30 largest corporations. Environmental Communication: A Journal of 
Nature and Culture, 3(2):244-262. DOI: 10.1080/17524030902916632.

Iskender, M., \& Akin, A. (2010). Social self-efficacy, academic locus of control, and internet addiction. Computers \& Education, 54(4):1101-1106. DOI: 10.1016/j.compedu.2009.10.014.

Jaramillo, F., Mulki, J.P., \& Boles, J.S. (2012). Bringing meaning to the sales job: The effect of ethical climate and customer demandingness. Journal of Business Research, 65(7):937-943. DOI: 10.1016/j.jbusres.2012.03.013.

Jenkins, A.S., Wiklund, J., \& Brundin, E. (2012). Individual responses to firm failure: Appraisals, grief, and the influence of prior failure experience. Journal of Business Venturing (2012). DOI: 10.1016/j.jbusvent.2012.10.006.

Joo, Y.J., Lim, K.Y., \& Kim, J. (2013). Locus of control, self-efficacy, and task value as predictors of learning outcome in an online university context. Computers \& Education, 62(2013):149-158. DOI: 10.1016/j.compedu.2012.10.027.

Kickul, J., Gundry, L.K., Barbosa, S.D., \& Whitcanack, L. (2009). Intuition versus Analysis? Testing differential models of cognitive style on entrepreneurial self-efficacy and the new venture creation process. Entrepreneurship Theory and Practice, 33(2):439-453. DOI: 10.1111/j.1540-6520.2009.00298.x.

Kohlberg, L. (1984). The psychology of moral development. San Francisco: Harper \& Row.

Kohlberg, L. (1981). The philosophy of moral development. New York: Harper \& Row.

Kohlberg, L. (1969). Stages in the development of moral thought and action. New York: Holt, Rinehart \& Winton.

Kok, G., Den Boer, D., DeVries, H., Gerards, F., Hospers, H. J., \& Mudde, A.N. (1992). Self-efficacy and attribution theory in health education. In: R Schwarzer (ed). Self-efficacy: Thought control of action. Washington, DC: Hemisphere.

Krige, D. (2012). Fields of dreams, fields of schemes: ponzi finance and multi-level marketing in South Africa. Africa, 82(01), 69-92. DOI: $10.1017 /$ S0001972011000738

Laratta, R. (2009). Ethical climate in nonprofit organisation s: a comparative study. International Journal of Sociology and Social Policy, 29(7/8):358-371. DOI: 10.1108/01443330910975678.

Locke, E.A., \& Latham, G.P. (2009). Has goal setting gone wild, or have its attackers abandoned good scholarship? The Academy of Management Perspectives, 23(1):17-23. DOI: 10.5465/AMP.2009.37008000.

Lopez, S.J., Floyd, R.K., Ulven, J.C., \& Snyder, C.R. (2000). Hope therapy: Helping clients build a house of hope. In: CR Snyder (ed). Handbook of hope: Theory, measures, and applications. San Diego, CA: Academic Press.

Luthans, F. (2002). Positive organisational behaviour: Developing and managing psychological strengths. Academy of Management Executive, 16(1):57-74. DOI: 10.5465/AME.2002.6640181.

Luthans, F., \& Jensen, S.M. (2002). Hope: A new positive strength for human resource development. Human Resource Development Review, 1(3):304-322. DOI: 10.1177/1534484302013003.

Luthans, F., Norman, S. M., Avolio, B. J., \& Avey, J. B. (2008). The mediating role of psychological capital in the supportive organizational climate - employee performance relationship. Journal of Organizational Behavior, 29(2), 219-238. DOI: 10.1002/job.507

Luthans, F., \& Youssef, C.M. (2007). Emerging positive organizational behavior. Journal of Management 33, 321-349. doi: $10.1177 / 0149206307300814$

Lynch, W.F. (1965). Images of hope: Imagination as healer of the hopeless. Baltimore: Helicon.

Maslow, A.H. (1970). Motivation and personality. $2^{\text {nd }}$ Ed. New York: Harper \& Row.

Magaletta, P.R., \& Oliver, J.M. (1999). The hope construct, will and ways: Their relations with self-efficacy, optimism, and general well-being. Journal of Clinical Psychology, 55(5):539-551. DOI: 10.1002/(SICI)1097-4679(199905).

Magyar-Moe, J.L., Edwards, L.M., \& Lopez, S.J. (2001). A new look at the working alliance: Is there a connection with hope? Unpublished manuscript. Department of Psychological Research and Education, University of Kansas, Lawrence.

McGee, J.E., Peterson, M., Mueller, S.L., \& Sequeira, J.M. (2009). Entrepreneurial self-efficacy: refining the measure. Entrepreneurship theory and practice, 33(4):965-988. DOI: 10.1111/j.1540-6520.2009.00304.x.

Melges, R., \& Bowlby, J. (1969). Types of hopelessness in psychopathological processes. Archives of General Psychiatry, 20, 690-699.

Mencl, J., Tay, L., Schwoerer, E., \& Drasgow, F. (2012). Evaluating quantitative and qualitative types of change: An analysis of the malleability of general and specific self-efficacy constructs and measures. Journal of Leadership \& organisational Studies, 19(3):378-391. DOI: 10.1177/1548051812442968.

Menninger, K. (1959). The academic lecture on hope. The American Journal of Psychiatry, 109:481-491.

Nam, S.K., Yang, E., Lee, S.M., Lee, S.H., \& Seol, H. (2011). A psychometric evaluation of the career-decision self-efficacy scale with Korean students: A Rasch model approach. Journal of Career Development, 38(2):147-166. DOI: $10.1177 / 0894845310371374$.

Nelson, J. K., Poms, L. W., \& Wolf, P. P. (2012). Developing efficacy beliefs for ethics and diversity management. Academy of Management Learning \& Education, 11(1), 49-68. DOI: 10.5465/amle.2009.0115

Newell, A., \& Simon, H.A. (1972). Human problem solving. Englewood Cliffs, NJ: Prentice Hall.

O'Sullivan, G. (2011). The relationship between hope, eustress, self-efficacy, and life satisfaction among undergraduates. Social indicators research, 101 (1), 155-172. DOI 10.1007/s11205-010-9662-z

Patrick, L., Care, E., \& Ainley, M. (2011). The relationship between vocational interests, self-efficacy and achievement in the prediction of educational pathways. Journal of Career Assessment, 19(1):61-74. DOI: 10.1177/1069072710382615.

Post, J.E., Lawrence, A., \& Weber, J. (2002). Business and society: Corporate strategy, public policy, ethics. $10^{\text {th }}$ Ed. New York: McGraw-Hill. 
Resnik, D. B. (2010). What is ethics in research \& why is it important. Research Triangle Park, North Carolina: National Institute of Environmental Health Sciences/National Institute of Health.

Rotter, J.B. (1966). Generalized expectancies for internal versus external locus of control of reinforcement. Psychological monographs, 80(1): 1-28.

Scherer, M., Maddux, J.E., Mercandante, B., Prentice-Dunn, S., Jacobs, B., \& Rogers, R.W. (1982). Self-efficacy scale: construction and validation. Psychological Reports, 51(2):663-671. DOI: 10.2466/pr0.1982.51.2.663.

Schneider, B. (1983). Work climates: An integrationist perspective. In: NW Feimer \& ES Geller (eds.). Environmental Psychology: Directions and perspectives. New York: Praeger.

Schunk, D.H. (1981). Modelling and attributional effects on children's achievement: A self-efficacy analysis. Journal of Educational Psychology, 73(1):93-105. DOI: 10.1037/0022-0663.73.1.93.

Seidenberg, I. (1998). Ethics as a competitive edge. Sears Lectureship in Business Ethics, Centre for Business Ethics, Bentley College, Waltham, MA, 13 April.

Shacklock, A., Manning, M., \& Hort, L. (2011). Ethical Climate Type, Self-Efficacy, and Capacity to Deliver Ethical Outcomes in Public Sector Human Resource Management. Journal of New Business Ideas \& Trends, 9(2).

Shafer, W.E. (2009). Ethical climate, organisational -professional conflict, and organisational commitment: A study of Chinese auditors. Accounting, Auditing \& Accountability Journal, 22(7):1087-1110. DOI 10.1108/09513570910987385.

Shafer, W.E., \& Simmons, R.S. (2011). Effects of organisational ethical culture on the ethical decisions of tax practitioners in mainland China. Accounting, Auditing \& Accountability Journal, 24(5):647-668. DOI: 10.1016/j.jbusres.2012.03.013.

Shantz, A., \& Latham, G.P. (2012). Transfer of training: Written self-guidance to increase self-efficacy and interviewing performance of job seekers. Human Resource Management, 51(5):733-746. DOI:10.1002/hrm.21497.

Shin, Y. (2012). CEO ethical leadership, ethical climate, climate strength, and collective organisational citizenship behavior. Journal of Business Ethics, 108(3):299-312. DOI: 10.1007/s10551-011-1091-7.

Simha, A., \& Cullen, J.B. (2012). Ethical climates and their effects on organisational outcomes: Implications from the past and prophecies for the future. Academy of Management Perspectives, 26(4):20-34. DOI: 10.5465/amp.2011.0156.

Sims, R.L. (1992). The challenge of ethical behavior in organisation s. Journal of Business Ethics, 11(7):505-13. DOI $10.1108 / 01443330910975678$.

Sitzmann, T., \& Ely, K. (2011). A meta-analysis of self-regulated learning in work-related training and educational attainment: What we know and where we need to go. Psychological Bulletin, 137(3):421-442. DOI: 10.1037/a0022777.

Snyder, C.R. (1994a). Hope and optimism. In: VS Ramachandren (ed). Encyclopedia of Human Behavior, 2:535-542. San Diego, CA: Academic Press.

Snyder, C.R. (1994b). The psychology of hope: You can get there from here. New York: Free Press.

Snyder, C.R. (1995). Conceptualizing, measuring, and nurturing hope. Journal of Counselling and Development, 73:355-360.

Snyder, C.R. (1998). A case for hope in pain, loss, and suffering. In: JH Harvey, J Omarzu \& E Miller (eds). Perspectives on loss: A sourcebook. Washington, DC: Taylor \& Francis.

Snyder, C.R. (2000). The past and future of hope. Journal of Social and Clinical Psychology, 19:11-28.

Snyder, C.R. (2002). Hope theory: Rainbows in the mind. Psychological Inquiry: An International Journal for the Advancement of Psychological Theory, 13(4):249-275. DOI: 10.1207/S15327965PLI1304_01.

Snyder, C.R., Cheavens, J., \& Sympson, S.C. (1997). Hope: An individual motive for social commerce. Group Dynamics: Theory, Research, and Practice, 1:107-118.

Snyder, C.R., Cheavens, J., \& Michael, S.T. (1999). Hoping. In: CR Snyder (ed). Coping: The psychology of what works. New York: Oxford University Press.

Snyder, C.R., Feldman, D.B., Taylor, J.D., Schroeder, L.L., \& Adams III, V.H. (2000). The roles of hopeful thinking in preventing problems and enhancing strengths. Applied and Preventive Psychology, 9(4):249-269. DOI: 10.1016/S09621849(00)80003-7.

Snyder, C.R., Irving, L., \& Anderson, J.R. (1991). Hope and health: Measuring the will and the ways. In: CR Snyder \& DR Forsyth (eds). Handbook of social and clinical psychology: The health perspective. Elmsford, NY: Pergamon.

Snyder, C.R., LaPointe, A.B., Crowson Jr., J.J., \& Early, S. (1998). Preferences of high- and low-hope people for self-referential input. Cognition \& Emotion, 12, 807-823. DOI: 10.1080/026999398379448.

Snyder, C.R., Rand, K., King, E., Feldman, D., \& Taylor, J. (2002). "False” hope. Journal of Clinical Psychology, 58:100-1022.

Snyder, C.R., Sympson, S.C., Ybasco, F.C., Borders, T.F., Babyak, M.A., \& Higgins, R.L. (1996). Development and validation of the state hope. Scale Journal of Personality and Social Psychology, 70(3):321-335.

Srinivasan, V. (2011). Business ethics in the South and South East Asia. Journal of Business Ethics, 104(1):73-81. DOI $10.1007 / \mathrm{s} 10551-012-1264-\mathrm{z}$.

Stajkovic, A.D., \& Luthans, F. (1998). Self-efficacy and work related performance: a meta-analysis. Psychological Bulletin, 124(2):240-261.

Staples, D.S., Hulland, J.S., \& Higgins, J.A. (1998). A self-efficacy theory explanation for the management of remote workers in virtual organisations. Journal of Computer-Mediated Communication, 3(4):0. DOI: 10.1111/j.10836101.1998.tb00085.x.

Stotland, E. (1969). The psychology of hope. San Francisco: Jossey-Bass.

Tierney, P., \& Farmer, S.M. (2011). Creative self-efficacy development and creative performance over time. Journal of Applied 
Psychology, 96(2):277-293. DOI: 10.1037/a0020952.

Tumasjan, A., \& Braun, R. (2012). In the eye of the beholder: How regulatory focus and self-efficacy interact in influencing opportunity recognition. Journal of Business Venturing, 27:622-636. DOI: 10.1016/j.jbusvent.2011.08.001.

Valle, M.F., Huebner, E.S., \& Suldo, S.M. (2006). An analysis of hope as a psychological strength. Journal of School Psychology, 44(5):393-406. DOI: 10.1016/j.jsp.2006.03.005.

Van Vuuren, L.J. (2002). Institutionalising business ethics: a multi-level ethics strategy. Management Dynamics, 11(2):21-27.

Van Yperen, N.W. (1998). Informational support, equality and burnout: The moderating effect of self-efficacy. Journal of Occupational and organisational Psychology, 71:29-33. DOI: 10.1111/j.2044-8325.1998.tb00660.x.

Victor, B., \& Cullen, J.B. (1988). The organisational bases of ethical climates. Administrative Science Quarterly, 33(1):101-125.

Victor, B., \& Cullen, J.B. (1987). A theory and measure of ethical climates in organisation s. Research in Corporate Social Performance and Policy, 9:51-71.

Vorster, J. M. (2011). An ethics of hope for moral renewal in South Africa. Journal of Theology for Southern Africa, 140, 4-19.

Walker, K.D. (2006). Fostering hope: a leader's first and last task. Journal of Educational Administration, 44(6):540-569. DOI: $10.1108 / 09578230610704783$.

Walumbwa, F. O., Mayer, D. M., Wang, P., Wang, H., Workman, K., \& Christensen, A. L. (2011). Linking ethical leadership to employee performance: The roles of leader-member exchange, self-efficacy, and organizational identification. Organizational Behavior and Human Decision Processes, 115(2), 204-213. DOI: org/10.1016/j.obhdp.2010.11.002

Wang, Y., \& Hsieh, H. (2012). Organisational ethical climate, perceived organisational support, and employee silence: A crosslevel investigation. Human Relations, 65(11):1-20. DOI: 10.1177/0018726712460706

Weinberg, R.S., Gould, D., \& Jackson, A. (1979). Expectations and performance: An empirical test of Bandura's self-efficacy theory. Journal of Sport Psychology, 1(4): 320-331.

Weis, R., \& Speridakos, E.C. 2011. A meta-analysis of hope enhancement strategies in clinical and community settings. Psychology of Well-Being: Theory, Research and Practice, 1:5. DOI:10.1186/2211-1522-1-5

Williams, B. (1985). Ethics and the Limits of Philosophy. Cambridge, MA: Harvard University Press.

Wood, R.E., \& Bandura, A. (1989). Social cognitive theory of organisational management. Academy of Management Review, 14(3):361-384.

Yavas, U., Babakus, E., \& Karatepe, O.M. (2013). Does hope moderate the impact of job burnout on frontline bank employees' in-role and extra-role performances? International Journal of Bank Marketing, 31(1):56-70. DOI $10.1108 / 02652321311292056$.

Zullig, K.J., Teoli, D.A., \& Valois, R.F. (2011). Evaluating a brief measure of social self-efficacy among US adolescents. Psychological Reports, 109(3): 907-920. DOI 10.2466/02.09.PR0.109.6.907-920. 